\title{
At-risk youths' self-sufficiency: The role of social capital and help-seeking orientation
}

Citation for published version (APA):

Schenk, L., Sentse, M., Lenkens, M., Engbersen, G., van de Mheen, D., Nagelhout, G. E., \& Severiens, S. (2018). At-risk youths' self-sufficiency: The role of social capital and help-seeking orientation. Children and Youth Services Review, 91, 263-270. https://doi.org/10.1016/j.childyouth.2018.06.015

Document status and date:

Published: 01/08/2018

DOI:

10.1016/j.childyouth.2018.06.015

Document Version:

Publisher's PDF, also known as Version of record

Document license:

Taverne

Please check the document version of this publication:

- A submitted manuscript is the version of the article upon submission and before peer-review. There can be important differences between the submitted version and the official published version of record.

People interested in the research are advised to contact the author for the final version of the publication, or visit the DOI to the publisher's website.

- The final author version and the galley proof are versions of the publication after peer review.

- The final published version features the final layout of the paper including the volume, issue and page numbers.

Link to publication

\footnotetext{
General rights rights.

- You may freely distribute the URL identifying the publication in the public portal. please follow below link for the End User Agreement:

www.umlib.nl/taverne-license

Take down policy

If you believe that this document breaches copyright please contact us at:

repository@maastrichtuniversity.nl

providing details and we will investigate your claim.
}

Copyright and moral rights for the publications made accessible in the public portal are retained by the authors and/or other copyright owners and it is a condition of accessing publications that users recognise and abide by the legal requirements associated with these

- Users may download and print one copy of any publication from the public portal for the purpose of private study or research.

- You may not further distribute the material or use it for any profit-making activity or commercial gain

If the publication is distributed under the terms of Article $25 \mathrm{fa}$ of the Dutch Copyright Act, indicated by the "Taverne" license above, 


\title{
At-risk youths' self-sufficiency: The role of social capital and help-seeking orientation
}

\author{
Loïs Schenk ${ }^{\mathrm{a}, *}$, Miranda Sentse ${ }^{\mathrm{b}}$, Margriet Lenkens ${ }^{\mathrm{c}, \mathrm{d}}$, Godfried Engbersen ${ }^{\mathrm{e}}$, \\ Dike van de Mheen $^{\mathrm{c}, \mathrm{d}, \mathrm{f}}$, Gera E. Nagelhout ${ }^{\mathrm{d}, \mathrm{g}}$, Sabine Severiens ${ }^{\mathrm{a}}$ \\ a Department of Psychology, Education and Child Studies, Erasmus University Rotterdam, Rotterdam, The Netherlands \\ ${ }^{\mathrm{b}}$ Institute of Criminal Law and Criminology, Leiden, The Netherlands \\ ${ }^{\mathrm{c}}$ Erasmus Medical Centre, Rotterdam, The Netherlands \\ d IVO Addiction Research Institute, The Hague, The Netherlands \\ e Department of Public Administration and Sociology, Erasmus University Rotterdam, Rotterdam, The Netherlands \\ ${ }^{\mathrm{f}}$ Tranzo, School of Social and Behavioral Sciences, Tilburg University, Tilburg, The Netherlands \\ ${ }^{\mathrm{g}}$ Department of Health Promotion, Department of Family Medicine, Maastricht University (CAPHRI), Maastricht, The Netherlands
}

\begin{abstract}
A B S T R A C T
Youths' help-seeking orientation on the individual level, and the presence of bonding and bridging social capital at the contextual level, are important factors in explaining at-risk urban youths' self-sufficiency. We conducted semi-structured interviews with 22 at-risk youths aged 15-25 years in an urban area, to study youths' perceptions of help-seeking and social capital. Consequently, we attempted to uncover the associations between these concepts. The results indicate that only few youths had positive help-seeking orientations, irrespective of their preference for self-reliance. Sources of help that youths feel comfortable to activate in their immediate environment are limited, but support is also found in extended family members. Bridging social capital is mainly provided by professionals and comprises instrumental and informational support. Many youths believe they can be understood only by individuals who are similar to them, but simultaneously indicate a need for additional support from significant others.
\end{abstract}

\section{Introduction}

For many individuals, adolescence is a period characterized by changes such as cognitive and social developments. When there is a good fit between the needs of adolescents and support in their social environments, these developments will usually result in opportunities for growth and more independence (Arnett, 2004; Eccles et al., 1993). At the same time, young people are expected to take more responsibility for their own lives. There is a growing emphasis on self-sufficiency, which has been referred to as "Big Society" in the United Kingdom and "Participation Society" in the Netherlands (The Netherlands Institute for Social Research, 2014). Self-sufficiency requires both the capability of insight into one's situation and the availability of sources of help when one is not capable of handling challenges (Lauriks et al., 2014).

As the previous definition shows, self-sufficiency depends on two conditions. First, self-sufficiency requires insight in one's situation and needs. Previous research on this dimension of self-sufficiency focuses on perceived barriers and facilitators in help-seeking, known as helpseeking orientation (Stanton-Salazar \& Spina, 2000; Tolsdorf, 1976). Help-seeking orientation is the perception of help which is shaped by one's belief of influence, need, and expectations of the usefulness of a network (Tolsdorf, 1976; Vaux, Burda, \& Stewart, 1986). The second dimension of self-sufficiency relates to the availability of sources of help, also known as the social capital of an individual. Social capital is the product of social support based on generalized or interpersonal trust, reciprocity, information, and cooperation in social networks (Putnam, 2000). Given the societal emphasis on self-sufficiency, when judging its feasibility both factors need consideration. For example, if youths have insight into their situation and needs, but lack the appropriate sources for help, they will more likely struggle to become selfsufficient. Conversely, when youths have access to supportive resources but do not think they need support, the question rises if they are selfsufficient enough. The expectation of youths who are transitioning to adulthood to become self-sufficient ignores the fact that youths might

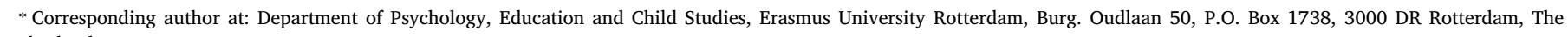
Netherlands.

E-mail addresses: 1.schenk@essb.eur.nl (L. Schenk), m.sentse@law.leidenuniv.nl (M. Sentse), lenkens@ivo.nl (M. Lenkens), engbersen@essb.eur.nl (G. Engbersen), h.vdmheen@uvt.nl (D. van de Mheen), nagelhout@ivo.nl (G.E. Nagelhout), severiens@essb.eur.nl (S. Severiens). 
perceive their situation in a different way than adults or professionals do. It also ignores the fact that resources to support self-sufficiency might be limited for some youths.

Studying factors that influence youths' opportunity for self-sufficiency at multiple levels (i.e. perceptions on the individual level and social capital at the contextual level) contributes to the expanding body of knowledge of positive youth development (Jenson \& Fraser, 2015). Conditions that young people need if they are to develop optimally include factors that make youths more resilient, more resistant to stressful conditions, and more likely to grow into healthy adults. Positive perceptions of one's situation (e.g. optimism, control, responsibility) are individual protective factors when they empower youth to solve problems (McCrae \& Costa, 2003; Rotter, 1966; Rutter, 1987). However, these protective factors interact with risk factors in the environments of youths. Growing up in an urban area is an important contextual factor in studying the perceptions of youth. Social support and social embeddedness have been identified as relevant protective factors on the contextual level (Groenendaal \& van Yperen, 1994; Jenson \& Fraser, 2015; Ungar, 2015). However, many youths in urban areas live in low-income families and disadvantaged neighborhoods. Consequently, they may experience closed-opportunity structures which can hinder social support and social embeddedness (StantonSalazar \& Spina, 2000). In interaction with personal risk factors, these youths are at risk of negative outcomes, such as academic failure, substance use, or unemployment (Jenson \& Fraser, 2015). Therefore, protective factors at the individual level become relevant in the context of the urban environment. As such, how at-risk youths perceive their situation and whether they need help is shaped by both individual beliefs and the availability of social support at the contextual level. The aim of this study is to elucidate how at-risk urban youths cope with the societal emphasis on self-sufficiency by exploring their own perceptions of their situation and social capital. These elements have separately been found to be related to self-sufficiency, but they have not been examined in relation to each other (Barwick, de Man, \& McKelvie, 2009). Since we assume that it is not actual support which shapes youths' opportunities for self-sufficiency, but rather their perceptions and willingness to use support resources (Goodwin-Smith et al., 2017; Vaux et al., 1986), we conducted qualitative research to gain insight into this.

\subsection{Beliefs and preferences concerning self-sufficiency}

Previous research has focused on youths' help-seeking orientation as one of the indicators of self-sufficiency. Help-seeking is seeking help in terms of understanding, advice, information, treatment, and general support (Rickwood, Deane, Wilson, \& Ciarrochi, 2005) from informal sources (e.g. friends, family, and mentors) or formal sources (e.g. teachers, youth workers, mental health services). Beliefs of helpfulness, problem recognition, and the availability of sources of help are related to a positive help-seeking orientation (Rickwood et al., 2005). A review of both quantitative and qualitative research into barriers to, and facilitators of help-seeking resulted in a classification of reasons for seeking or not seeking help (Gulliver, Griffiths, \& Christensen, 2010). Motivators for seeking help included having had positive past experiences of the care that was provided, positive relationships with service staff, and social support. The barriers identified in this review included preferring other sources of help, not wanting to burden someone else, and reliance on oneself (Gulliver et al., 2010).

Research on the help-seeking behavior of youths has mainly focused on help-seeking with regard to resolving emotional or behavioral problems. Staying in school and finding employment are examples of equally important issues for at-risk youths. Research on college students asking for academic and career help, for example, also showed selfreliance as a barrier, in addition to a perceived unavailability of adults who they needed support from (Schwartz, Kanchewa, Rhodes, Cutler, \& Cunningham, 2016). In addition, beliefs about one's control over their life has been consistently linked to help-seeking orientation, and plays a major role in becoming self-sufficient (DePaulo, Fisher, \& Nadler, 1983; Schonert-Reichl \& Muller, 1996). For example, self-reliance - the preference to solve problems on one's own- has been found to be a coping strategy that reduces the use of both formal and informal support (Ortega \& Alegría, 2002; Scott, McMillen, \& Snowden, 2015).

In summary, help-seeking is considered part of adolescents' and young adults' establishment of self-sufficiency. A positive help-seeking orientation is fundamental to resiliency (Stanton-Salazar \& Spina, 2000). The role of self-reliance and the availability of others appear to be important factors in barriers to, and facilitators of, help-seeking among adolescents. To investigate the elements necessary for self-sufficiency of at-risk youths, it is important to start with the beliefs, preferences, and expectations of at-risk youths concerning help and support.

\subsection{Social capital}

The above-mentioned barriers show that not only past experiences and beliefs about one's control are of importance in help-seeking, but also the presence of, belief in, attitude towards and expectations concerning the usefulness of one's network (Tolsdorf, 1976; Vaux et al., 1986). Social networks are sources of social capital and have been studied as another indicator of self-sufficiency.

Social capital can be divided into two types: bonding and bridging. Bonding social capital refers to trusting and co-operative relations between members of a network who perceive themselves to be similar in terms of their shared social identity (Granovetter, 1973; Putnam, 2000; Szreter \& Woolcock, 2004). For youths, this consists primarily of relationships with parents, siblings, other family members, and peers (Bassani, 2007; Bottrell, 2009; Raymond-Flesch, Auerswald, McGlone, Comfort, \& Minnis, 2017). Networks consisting of individuals with a shared social identity are characterized by frequent contact, and therefore this type of network mainly provides emotional support (Stanton-Salazar \& Spina, 2005). Bridging social capital refers to resourceful relations with people who do not share a common social or socio-demographic identity and who provide access to new and valuable information (Granovetter, 1973; Putnam, 2000; Szreter \& Woolcock, 2004). For youths, bridging contacts could be teachers, counselors, healthcare providers, and other adults in their community (Resnick et al., 1997). The primary purpose of these relations is often instrumental, providing guidance, advice, and tangible assistance that is not present in the bonding social network.

Bridging social capital could be particularly important for at-risk youths because it provides them with richer resources and alternative perspectives on, among other things, education and health (Bassani, 2007; Bottrell, 2009; Ellison, Wohn, \& Greenhow, 2014). However, previous research found that American adolescents from low income families and/or neighborhoods had less access to bridging supportive adults compared to adolescents from higher income families (Raposa, Erickson, Hagler, \& Rhodes, 2018). If they did have access to a supportive nonparental adult, this adult often appeared to be a family member, instead of a bridging contact.

Ferguson's (2006) meta-analysis showed that family structure (single-parent versus two-parent households, the presence of a paternal figure), social relationships, supportive social networks, and links to local organizations and institutions are indicators of the social capital of young people. However, in accordance with Putnam's view of social capital, we want to pay attention to the fact that not all resources are considered capital. Scholars have stressed that only in positive and active relations, resources can be mobilized in order to serve as capital (Bassani, 2007; Portes, 1998). Additionally, claiming something to be social capital because it is valued by privileged groups in society does not address the needs of at-risk youths (Yosso, 2005). Positive relations will also be shaped by cultural capital, examples of which are language and appearance (Bourdieu, 1986). These indicators of cultural capital 
will contribute to youths' perceptions of others' social identity. Youth, in turn, may perceive these social identities as either shared or nonshared. Therefore, Bourdieu's notion of cultural capital (1986) has a significant contribution to studying bonding and bridging social capital.

Previous qualitative research on the bonding and bridging social capital of adolescents has been done among urban girls in Australia and youths in rural settings in the United States. In a sample of American youths, bridging social capital emerged from civic engagement, volunteering activities, and going to church (Ellison et al., 2014). Studies on youths dealing with disadvantage, however, demonstrated that youths felt the need for other adults to provide them with help to navigate structural systems in education, employment, and healthcare. The bridging capital that was present usually comprised contact with community agencies rather than informal providers of support (Bottrell, 2009; Raymond-Flesch et al., 2017). Although scholars have emphasized the necessity of studying help-seeking orientations regarding access to the networks of minority adolescents, little research has been done to investigate the links between types of social capital and the help-seeking orientation of at-risk urban youth (Stanton-Salazar \& Spina, 2000). The relevance of social capital in relation to formal and informal sources of help has been shown in a recent study among 589 American rural adolescents. Adolescents with higher levels of bonding social capital were more willing to seek informal help and, in turn, were more willing to seek professional help (Hedge, Sianko, \& McDonell, 2017). Seeking help will be less difficult when supportive relationships are established and knowing who is available will make adolescents more capable of seeking informal help when needed. Subsequently, the friends and family of adolescents may encourage them to seek professional help by providing information and instrumental support. It is therefore relevant to study the sources of social capital that at-risk youths perceive as helpful in becoming self-sufficient.

The present study further explores the relation between helpseeking and social capital as conditions for self-sufficiency. Past research has identified barriers and facilitators relating to adolescent help-seeking, which often relies on social relationships. However, it remains unclear how these conditions for self-sufficiency are experienced by at-risk urban youths and how different social networks provide different kinds of support. For this reason, we have used a qualitative method to study youths' perceptions of their situation, needs, and social support.

\section{Method}

\subsection{Participants}

A sample of 22 vulnerable youths from Rotterdam participated in semi-structured interviews. Rotterdam is the second most populous city in the Netherlands. It is known for its relatively poor and ethnically diverse population, as well as its high youth unemployment rates. Rotterdam has approximately 7000 youths at risk, defined as young people between the ages of 12 and 27 years who pose a risk to themselves and/or society due to an accumulation of problems with work, school, health, and/or security (Scheidel, 2016). To gain information on youths' experiences of formal help-seeking, we only included youths in our sample who were or are in formal care- or support systems. At-risk youths in this research refers to young people between the ages of 15 and 25 years ( $m=18.3$ years) who have been identified by professionals in the juvenile criminal justice system, youth care sector, or school attendance officers. Seventeen of the respondents were receiving support at time of the interview (in a judicial institution, or by a social or probation worker), while five of them had experienced problems in the past but were receiving no formal help at the time of the interview.

Consistent with the population of the city of Rotterdam, a relatively large portion of the sample was from an ethnic minority. Seventeen youths were born in the Netherlands, 20 respondents were of non-native Dutch descent (using the definition of Statistics Netherlands, which considers a person to be of native Dutch descent if both of his or her parents were born in the Netherlands). Of the 20 non-native Dutch participants, five had a Moroccan background, eight a Caribbean background, and seven had other ethnic backgrounds. The professionals had more boys than girls in their caseload, and therefore only two girls were included in the sample. For this reason, the results will apply mainly to at-risk boys and statements about gender differences cannot be made.

The recruitment of participants took place between March and November 2016 through contacts with professionals working in youth care, schools or the criminal justice system (e.g. psychologists, youth coaches, social workers, school attendance officers). The researchers also joined activities in which potential respondents could be found, such as meetings between school attendance officers and youths who had played truant, outreach workers doing their rounds in disadvantaged neighborhoods in Rotterdam, and hearings of the sub-district court with truant youth. A third sampling strategy was snowball sampling, which is a beneficial technique to gain access to vulnerable populations such as at-risk youths (Sadler, Lee, Lim, \& Fullerton, 2010).

\subsection{Data collection}

The interviews were conducted by the first and third authors of this paper. They took place at locations to which the respondents could easily travel and at which they would feel comfortable, such as the central library. In the case of closed facilities for youth care or imprisonment, the interview was conducted on location.

All the participants signed an informed consent form, and extra assents (tacit) were obtained from the parents of participants under the age of 16 . The participants were interviewed individually by one of the two researchers and were asked to provide pseudonyms under which their interview would be transcribed. All the interviews were audio recorded and lasted between 60 and $90 \mathrm{~min}$ each. Participation was voluntary, and the participants were compensated with 15 Euros after the interview was conducted. The study was not subject to the Medical Research (Human Subjects) Act. This qualitative research was part of a broader research project on at-risk youths in Rotterdam, conducted by the Erasmus Urban Youth Lab, and had an explorative character (see also Lenkens et al., 2018). The focus of the topic list was the lives and perceptions of youths regarding barriers and support in multiple life domains.

Questions were related to the participant's perceptions of their situation and included the youths' views on their current situation and beliefs about the causes of their situation and support. For example, "Are you satisfied with the situation you are in?" followed by "Why is this the case? Who is responsible for this?" Perceived social support was used as an indicator of social capital. To gain insight into the youths' social capital, topics such as perceived support of friends, family, and other important adults were addressed. Examples of questions include: "How is your relationship with your parents?" and "Who else is important to you?" Finally, to gain information about the youths' helpseeking orientation, the perceived need for support and formal care and the perceived quality of past support and care were addressed. Examples of questions are: "What do you think of the help and support you receive(d)?" and "Do you think that you need help right now?"

\subsection{Analysis}

The interviews were transcribed and coded in the qualitative data software NVivo. We analyzed the data using thematic content analysis, identifying the major themes regarding self-sufficiency from our data (Baarda, De Goede, \& Teunissen, 2005). During this process themes regarding social capital and help-seeking orientations were identified. Next, more focused coding took place, with social support divided according to the type of social capital and person (e.g. bonding and bridging relating to the father, mother, aunts, and friends), positive and 
negative perceptions, and type of support, such as emotional, informational, and instrumental support. Perceptions around help and support were divided into positive and negative experiences. Next, we checked the applicability of the resulting coding scheme to the rest of our data. Last, we assessed the importance of the main codes in relation to our central research questions (Baarda et al., 2005). The second level of analysis consisted of classifying and synthesizing codes, looking for patterns between concepts. The coding was carried out by the first author of this paper, in consultation with the second and last author. To ensure similar interpretations of the quotes used to illustrate the claims in this paper, they were translated, presented, and discussed with the second author.

\section{Results}

The youths in our sample had received several forms of informal and formal support, but youths emphasized the role that they themselves played in their lives. Indications of self-reliance and self-blame as barriers and facilitators of help seeking were most strongly present in the observed data, which will be presented below.

\subsection{Perception of situation: what happens to me is my own doing}

Not having a diploma, having trouble with (new) relationships, using drugs, and ongoing police contact are examples of problems the youths said they had encountered in their lives. Initially, they blamed themselves for these problems. For example, they did not feel motivated enough to quit using drugs, or they felt they could not resist going somewhere with friends instead of going to school. Milan thinks his biggest problem is not having a school diploma. When asked why these problems existed, he answered:

Milan (19): It's my fault [that I have no diploma...]. Maybe 10 to $20 \%$ of it is because of others, but mostly because of myself. [Those 10 to $20 \%$ are] my parents not chasing me up and friends who keep asking me to hang out with them when I have to do homework. It is distracting, but in the end it's my own fault, because I again choose to [hang out with them].

The above quotation illustrates the primary reaction of many of the respondents. Like Milan, the youths blamed themselves when asked who was responsible for their problems. They thought it was their own fault that the problems they mentioned existed or had not been solved yet. However, as the above quotation indicates, they did not think the problems were entirely their fault. This is observed with notable nuance: the youths blame themselves for the situations they are in, but also indicate external factors that influence their situation. Negative events, distracting friends, and unsupportive parents are part of the youths' explanations of why things happened.

Blaming oneself also seemed to have a positive or activating aspect, since in multiple interviews it appeared to be a motivator of change. Sometimes the situation had to become worse before they realized that things had to change. Karim, for example, had been institutionalized in order to be rehabilitated from his drug addiction two years before, but was not motivated enough and left after two weeks. After another negative life event, he was more motivated and he thus quit using drugs independently of supervision. Additionally, when asked what would work best for people in the same situation, the respondents frequently said to "leave them alone" (Jovani, 19) and "let them finish playing" (Travis, 21). This suggests that they thought people in the same position as them had to find out 'the hard way' that something had to change.

\subsubsection{Self-reliance}

Youths first and foremost preferred to rely on themselves, rather than seeking support from their social network or instances. "You have to want it yourself", "you have to learn it by yourself", "you have to make decisions by yourself", "you should be able to do it yourself", are statements many respondents made in response to the question about why certain support in the past did not work or would not work in the future.

A reason for this tendency towards self-reliance could be the assumption that others will not understand them since the youths feel that they are different from others. Ravi, having trouble to stay in school after a year of absenteeism, said he did not like people giving their opinions when they were not in the same situation as he was. He explained this in his answer to the question about whether the opinions of other people were important to him:

Ravi (19): No, not at all. In the end I am the one who makes my own money and pays my own bread, so the opinions of others don't matter to me. If they were in my shoes, maybe then it would [matter to $\mathrm{me}]$.

\subsection{Bonding social capital: parents and non-parental adults}

All the youths stated that they had friends with whom they spent a lot of time and who were important to them. Remarkably, when asked who was important for support during changes in their lives, friends played a significantly smaller role. Because of this finding, the focus of this section will be on parents and other (extended) family members.

With respect to family structure, only six of the 22 participants were living in two-parent households. The other youths (16 of the 22) were living without their fathers. The focus of these results will therefore be on the bonding social capital that their mothers provided, since parental support was mostly received from mothers.

\subsubsection{Not wanting to burden their mothers}

Most youths reported a good or even strong relationship with their mothers. They spoke of their relationships with their mothers in terms of being close and sharing a lot. This illustrates the type of support they perceived receiving mostly from their mothers, namely emotional support. While others described their relationships as good in the sense that "we do not have problems" or "she is my mother, I have only one of her", most of the respondents stated that they had good relationships with their mothers because they were close, they could talk and share feelings, or they felt understood. A distinctive finding was the fact that a large portion of the respondents felt uncomfortable about asking their mothers for help. Even though the youths described their relationships with their mothers as good and said they could easily talk to them, they mostly stated they did not have the need to do that. They often replied, "Oh, I don't feel the need to talk about my feelings to my mother".

Apart from this ambivalence, some youths also indicated they had the possibility to talk and share feelings with their mothers, but they felt they were a burden to them. Some respondents described the difficult conditions in which their mothers were living and therefore did not want to worry them. Johnny, who was living with his mother even though he had two children with his girlfriend, said he was very close to his mother. However, he did not want to burden her with his problems.

Johnny (26): I rather don't talk to my mother [about feelings]. My mother is very sensitive. I'd rather not bother her with my problems. She has her own problems and I'd rather let her live peacefully, without knowing my problems.

\subsubsection{Support from aunts}

Aunts were mentioned multiple times (in 10 out of 22 interviews) as important sources of support. In three of these cases, the so-called aunts were not blood relatives, but a friend of their mother or a former stepmother. Likely, they were considered as aunts because of their age and the structural presence in their lives. The reason for which the youths identified these aunts as significant in their lives was mostly that they offered emotional support. In multiple cases an aunt offered a place to stay for a time out until calm was restored at home. For 
example, Carlos, who was in juvenile rehabilitation two years ago, sometimes lives with his aunt when there is an argument at home:

Carlos (20): I am living at my aunt's place right now, because I had troubles with my dad; therefore [I live at my aunt's place now...]. I have stayed at her place often. My aunt is very important to me. She's very close to me.

Remarkably, it was not only the youths who reported a lack of emotional support from their own parents who emphasized the role of aunts in their lives. This indicates that emotional support from aunts is additional and not a substitute. From the youths' perspective, aunts are more able to relate to them. Karim's parents are both from Morocco. His parents have not received formal education, and they currently are not in paid employment. Karim has a very close relationship with his parents, but also emphasizes some qualities of his aunts:

Karim (25): My aunts are important. They are good, spirited aunts. Sometimes they understand me better and this makes me more open. They understand what I am dealing with and they explain things to me. They speak Dutch very well. They have a higher education and they speak different than 'normal' Dutch. They speak 'educated Dutch', so to speak.

In other words, Karim seemed to feel understood by his aunts because they had studied in the Netherlands and therefore might have understood his bicultural identity more than his parents did. Moreover, Karim seemed to imply that speaking Dutch on a 'higher level' had certain advantages that enabled his aunts to support him. Also, in other cases, aunts were appreciated because they seemed to provide additional support, over and above that of the parents. A respondent mentioned his 'smart' aunt as important, because for example, she advocated for him when his teacher recommended a level of high school that was lower than the results of the standardized CITO test indicated.

\subsection{Bridging social capital: key role of professionals from formal institutions}

Eight youths reported having bridging social capital contacts, of which only one reported informal bridging contacts. The other reported bridging social contacts were professionals. The interviews revealed certain key elements of what youths felt was helpful in terms of various types of help and support received from these contacts outside their bonding network. Mo for example, was thankful for the help that two youth coaches in his district offered before he was in detention.

Mo (18): I just met them on the street and they helped me. They're really of value to me and they call me weekly too [now that he is in detention].

Interviewer: What did they help you with?

Mo: I wanted to work, they helped me search. I dunno, man, [they helped me] with little things, but still I'm grateful. They took me to places, or they helped my mother - my mother is illiterate - reading letters that I didn't understand myself.

In the quotation above, Mo states that he appreciates the ways that youth coaches helped him and his mother with so-called 'little things'. This was the kind of support that many respondents mentioned as helpful. This 'simple' help was extremely important to them. Other examples of individuals who helped them were school career coaches helping with organizing agendas, teachers looking for suitable solutions for specific situations, social district team employees who were always available, juvenile probation officers who were helping them with handling fines, and supervisors in general who 'arranged things'. As the above quotation of Mo illustrates, youths appreciate bridging contacts who offer them instrumental support.

\subsubsection{Conditions for receiving support}

A condition that appeared to be important in order for bridging contacts to be of help was approachability, or the easy accessibility of the support. All the individuals who were labeled as helpful were praised because of their accessibility. Seeing someone on a regular basis reduced the barriers to communication.

A second condition under which respondents found it easier to receive support was that of similarity between the youth and the person offering support. To build a trusting relationship and receive support, the youths found it important that these people knew what they were talking about concerning the disadvantaged neighborhood the youths were living in and their cultural background. Both Mo and Johnny stressed the importance of similarity when asked how and why certain professional caregivers in their lives were of value.

Mo (18): The coach also grew up in a bad neighborhood. He's really very relaxed. He just felt us, because he's from the same neighborhood [...]. You can tell he has life experience. You can just tell.

Johnny (26): It's more like [being an] immigrant; there is a connection. You understand me, you know [...] you definitely have a couple of nephews on the streets as well, you just know [...]. You have to be familiar with street culture. That's also important.

The youths frequently expressed the need to feel understood by others but also showed a level of frustration that people who tried to help them could not understand them. People who they did feel would understand them were perceived to be similar in certain respects, such as cultural and migrant background, familiarity with street culture and so-called 'life experience'.

\subsection{Help-seeking orientation: no need for formal support or care}

Questions about the beliefs of the youths in our sample about the effectiveness of the formal help and support they had received yielded a relatively consistent picture. Most of the youths were negative or neutral about this. They either explicitly mentioned why they did not like the received care, or they accepted the care but did not find it useful, as the following quotation illustrates:

Milan (19): It was just nonsense. She [the therapist] only wanted to talk to me and that was it. Well, I didn't benefit from it that much. I think psychology is nonsense. I thought so before [I started therapy]. What would it help if someone talks to you?

The perceived need for support and care was very low, including the reasons mentioned above, such as not believing in the effectiveness of offered support. The youth indicated that they would rather rely on themselves.

In order to explore patterns in the youths' help-seeking and social capital we analyzed in more detail the transcripts of five youths who indicated that they were in need of help and had a positive help-seeking orientation. These youths, like the majority of our sample, showed certain degrees of self-reliance but, uniquely they did not point out external factors that they felt were influencing their lives in a negative way. In addition, they also indicated they had positive experiences of the care they had received in the past. Finally, an age pattern appeared under youths with a positive perception of help. Youths with a positive help-seeking orientation were in early adulthood (ages above 18 with a mean age of 21.4 years), whereas youths who indicated a negative perception of help were predominantly adolescents (with mean age of 17 years). No patterns were observed for type of risk, social capital, or ethnic descent.

In sum, the lack of assigning negative external factors as a barrier, having positive perceptions of past care, and older age seem to be prerequisites for youths to have a positive help-seeking orientation. The combination of the presence of these factors were unique for the youths with a positive perception of help, but some factors were present in other youths as well. This indicates that these factors are necessary, but not sufficient for a positive help-seeking orientation of at-risk youths. 


\section{Discussion}

In this study we set out to explore the perceptions of at-risk urban youths regarding their help-seeking orientations, insofar as these were shaped by their needs and social capital. Based on qualitative analyses of interviews with 22 at-risk youths in an urban city, this study illustrates the conditions for self-sufficiency: the presence of social capital and positive help-seeking orientations. Self-blame and self-reliance were important factors in youths' perception of their situation. Youths indicated that their bonding social capital was sufficient, but also indicated limitations and the need for other resources. Instrumental support by bridging contacts is mostly provided by formal resources, which seemed to be appreciated more when the youths perceived the professional to be similar in terms of cultural background and neighborhood. Only five at-risk youths had a positive help-seeking orientation.

\subsection{Youths' perceptions of their situation and needs}

The strong tendency towards self-reliance among youths in our study corresponds with previous findings of higher levels of self-reliance among youths facing adversity than those in normative sample (Gulliver et al., 2010). The present study shows that it can also be referred to as a coping style to deal with situations that are outside an individual's control, which has been labeled survivalist self-reliance in previous research (Samuels \& Pryce, 2008). A possible explanation for this self-reliance may be that the youths do not want to burden their families with their problems, mainly because their biggest sources of emotional support (their mothers) are already in challenging situations. Another possible explanation may be that the youths feel they can only be understood and helped by people who have had similar experiences to them. Since people who might give additional instrumental and informational support are mostly professionals who do not have a shared background, the youths do not think of these people as resources of support and therefore tend to prefer to be self-reliant.

\subsection{Social capital}

Youths stated that they received enough support from their parents, which was mostly in the form of emotional support from the mothers. Although youths did not make this explicit, their social capital might be limited due to the absence of a paternal figure. Non-parental adults, such as extended family members, appeared to contribute to the emotional support of at-risk youth. Especially for youths growing up in single-parent households, non-parental adults seem to be an important source of providing bonding social capital (Raymond-Flesch et al., 2017). The findings on the importance of aunts are also consistent with previous research on Caribbean families in the Netherlands. These families have matrifocal systems, in which fathers are relatively frequently absent and female members support each other (Distelbrink, 2000). This could explain the significant role aunts play in the lives of many at-risk youths in our sample.

Our findings show the need for support from adults who have more knowledge or experience, for example about the school system and other formal organizations. The youths in our study distinguish between the emotional support they receive from their mothers and the emotional support they receive from their aunts. Research into the educational achievements of successful second-generation immigrants in the Netherlands indicates that these youths value informed social support (Rezai, Severiens, \& Crul, 2017). This type of support is given by people who are more educated, familiar with the education system, and are also aware of the experiences and challenges these youths face. The present study suggests that this category of social support is not only applicable to educational achievement, but to adjustment of at-risk youths in general.

The literature suggests that bridging social capital is of immense importance for at-risk adolescents, since bridging actors can provide them with instrumental and informational support, as well as access to institutional resources (Bottrell, 2009). However, the current research shows that bridging social capital for many at-risk youths is present in a limited way. The bridging social capital that youths consider helpful comes from individuals affiliated with formal institutions, such as youth care or school, which is in accordance with previous research on bridging capital of youths in Australia and the United States (Bottrell, 2009; Raposa et al., 2018; Raymond-Flesch et al., 2017). The most distinctive feature of individuals providing bridging social capital is that they do not share a common social or sociodemographic identity with the youths (Szreter \& Woolcock, 2004). The youths in our sample, however, emphasized the importance of the similarity of helpful others regarding migration background and living conditions. These perceived similarities seem to refer to Bourdieu's notion of 'embodied cultural capital' (1986). One's language or accent, specific skills, and dispositions are examples of embodied cultural capital. The youths in our sample have a preference for helpful others whose embodied cultural capital is close to them. The preferences of these at-risk youth concerning support offer reflections on the theoretical value of bridging capital for at-risk youth which have, to the best of our knowledge, not been found in previous research.

\subsection{Help-seeking orientation}

Most youths have negative perceptions of past care, and do not articulate the need for further support. They think that talking about problems or other forms of therapy are not useful to them, especially when offered by someone they feel will not understand their situation. Concerning informal help, they indicate that they do not want to burden their mothers and therefore do not ask for emotional support (cf. Gulliver et al., 2010). Our findings indicate the importance of instrumental and informational support offered by extended familymembers and professionals who are perceived as similar to these at-risk youths.

The present study aimed to explore at-risk youths' help-seeking orientations in the context of their social support. Youths who do have a positive help-seeking orientation have had or are having positive experiences with present or past care, and do not cite external factors as the cause of their problems. This finding is partly consistent with the existing literature; individuals with an external locus of control tend to have a less positive attitude towards seeking professional help (Barwick et al., 2009) and individuals who have had positive experiences of care in the past have a more positive attitude towards seeking help (Gulliver et al., 2010). The combination of these two factors as conditions for seeking help highlights the need to consider youths' attitudes towards help-seeking. Additionally, youths with positive help-seeking orientations were the oldest in our sample. Possible explanations include older individuals being less likely to endorse social roles of strength, or having more life experience teaching them that seeking help is of value (Mackenzie, Gekoski, \& Knox, 2006). It remains unclear, however, if and how age is an indicator of positive perceptions of help.

It is also important to note that self-reliance in previous research has been identified as a barrier to seeking help (Gulliver et al., 2010; Ortega \& Alegría, 2002; Scott et al., 2015). Youths in our sample appeared to be self-reliant, but self-reliance was not absent among youths with a positive help-seeking orientation. Although self-reliance can be a source of risk, since it can indicate a difficulty to make connections with others and ask for support when needed, the present study did not always find this to be the case. Several youths indicated being both self-reliant and having a positive help-seeking orientation. Being self-reliant can also be a motivator to seek help. Self-reliance is related to having an internal locus of control, and the belief that change and improvement is possible may result in seeking help as an opportunity for improvement (Funch \& Marshall, 1984).

Further research is required on how the social capital of at-risk 
youth is related to their perceptions of help, since the current sample did not show much variation in bonding and bridging capital. We did not find evidence for the findings of Hedge et al. (2017) that the presence of bonding social capital increases help-seeking. The present study gives reason to further study the conditions under which at-risk youth have a more positive help-seeking orientation.

\subsection{Implications}

The findings of our research concerning the social capital of at-risk youth emphasize the role of non-parental adults in providing additional emotional, informational, and instrumental support. Additional emotional support was provided by familial adults such as aunts, but instrumental and informational support was often received from non-familial adults as well. At-risk youths may need more bridging sources of help in their network that are able to provide them with additional social capital. Therefore, we recommend interventions aimed at increasing the bridging social capital of at-risk youths. An example of such an intervention is mentoring. To expand social capital, mentors from outside the youths' networks can serve as bridging contacts. This research also indicates the need for youths to perceive bridging contacts as relatively similar to them. It is therefore important to explicitly identify the needs of at-risk youths to match them with an appropriate mentor.

At-risk youths who have access to bridging capital may not want to activate it because of the beliefs they have concerning the effectiveness and the competence of these individuals. For example, the present study indicates that the youths have access to emotional support from their mothers, but that they are hesitant to activate this. The same applies to support from professionals such as psychologists. Further research should therefore include a focus on the distinction between access to and activation of social capital (Lin, 1999; Smith, 2005), and how this is shaped by youths' network orientations (Vaux et al., 1986).

Recent research on an intervention that includes both mentoring and activation of capital, offers relevant directions for implications. A program designed to discuss barriers in help-seeking and the identification and activation of social support with youths appeared to be beneficial for first-generation college students. The program significantly influenced the students' college attitudes and behaviors related to the cultivation of social capital (Schwartz et al., 2016; Schwartz et al., 2018). Normalizing help-seeking behavior and framing it as a necessary component of development, rather than as a lack of self-reliance, allowed youths to engage in help-seeking (Schwartz et al., 2016). While promising, future studies are necessary to study the effectiveness of this intervention outside a school context, after assessing the expressed needs of at-risk youths.

The overrepresentation of males in our sample might explain the main finding that at-risk youths had a negative help-seeking orientation. Previous research on the help-seeking of adult males found that they tend to have more negative attitudes towards psychological help than other forms of assistance, which was related to their traditional masculine ideologies (Berger, Levant, McMillan, Kelleher, \& Sellers, 2005; Scott et al., 2015). Whereas male adolescents rely more heavily on stress reduction and diversion, female adolescents mobilize their social support more often (Copeland \& Hess, 1995). This suggests that support should be reconsidered for at-risk male youths. Researchers suggested that treatment (formal help) could focus more on thinking rather than on feeling, and that this would change perceptions of help seeking among males (Berger et al., 2005). How this would impact atrisk male youths' perceptions needs further attention in future research.

\subsection{Limitations of the present study}

There are several limitations to this study that require consideration. These include the gender balance of our sample, which consisted of 20 boys and two girls. Although relations between perceptions of their situation, social capital, and perceptions of help did not differ for the two girls in our sample, the results might be only generalizable to at-risk boys in urban areas. The qualitative nature of our study provided valuable insights into the perceptions of at-risk youths. However, youths may have felt less understood by interviewers with a different societal status and ethnic background, which could have affected their responses. The researchers' personal biases could also have affected their analyses. We attempted to mitigate these limitations by presenting ourselves as independent from the systems that youths were in for support or care, emphasizing their anonymity, and using multiple researchers to conduct the interviews and analysis.

\subsection{Conclusion}

This research was conducted to explore youths' social capital and help-seeking orientations within a context of societal expectations of self-sufficiency. Our findings suggest that at-risk youths' preference for self-reliance may be both a barrier to and facilitator of seeking help. Their need for self-reliance must be considered in the light of their limited bonding social capital, and their preference for similarities in their bridging social capital. Only when taking into account at-risk youths' preferences, past experiences, and expectations in seeking help, self-sufficiency can be expected.

\section{Declarations of interest}

None.

\section{Funding}

This research was funded by Erasmus University Rotterdam by means of a 'Research Excellence Initiative' grant.

\section{References}

Arnett, J. J. (2004). Emerging adulthood: The winding road from the late teens through the twenties. New York: Oxford University Press.

Baarda, D., De Goede, M., \& Teunissen, J. (2005). Basisboek kwalitatief onderzoek; han dleiding voor het opzetten en uitvoeren van kwalitatief onderzoek [basic book on qualitative research: Manual for designing and conducting qualitative research]. Houten, The Netherlands: Noordhoff Uitgevers BV.

Barwick, A. K., de Man, A. F., \& Mckelvie, S. J. (2009). Personality factors and attitude toward seeking professional help. North American Journal of Psychology, 11(2), 333-342. Retrieved from https://search.proquest.com/docview/198016429? accountid $=13598$.

Bassani, C. (2007). Five dimensions of social capital theory as they pertain to youth studies. Journal of Youth Studies, 10(1), 17-34. http://dx.doi.org/10.1080/ 13676260701196087.

Berger, J. M., Levant, R., Mcmillan, K. K., Kelleher, W., \& Sellers, A. (2005). Impact of gender role conflict, traditional masculinity ideology, alexithymia, and age on men's attitudes toward psychological help seeking. Psychology of Men \& Masculinity, 6(1), 73. http://dx.doi.org/10.1037/1524-9220.6.1.73.

Bottrell, D. (2009). Dealing with disadvantage: Resilience and the social capital of young people's networks. Youth Society, 40(4), 476-501. http://dx.doi.org/10.1177/ $0044118 X 08327518$.

Bourdieu, P. (1986). The forms of capital. In J. G. Richardson (Ed.). Handbook of theory and research for the sociology of education (pp. 241-258). New York: Greenwood Press.

Copeland, E. P., \& Hess, R. S. (1995). Differences in young adolescents' coping strategies based on gender and ethnicity. The Journal of Early Adolescence, 15(2), 203-219. http://dx.doi.org/10.1177/0272431695015002002.

Depaulo, B. M., Fisher, J. D., \& Nadler, A. (1983). New directions in helping. Academic Press.

Distelbrink, M. J. (2000). Opvoeden zonder man: Opvoeding en ontwikkeling in Creools Surinaamse een-en tweeoudergezinnen in Nederland. Assen: Van Gorcum.

Eccles, J. S., Midgley, C., Wigfield, A., Buchanan, C. M., Reuman, D., Flanagan, C., \& Mac Iver, D. (1993). Development during adolescence: The impact of stage-environment fit on young adolescents' experiences in schools and in families. American Psychologist, 48(2), 90-101. http://dx.doi.org/10.1037/0003-066X.48.2.90.

Ellison, N. B., Wohn, D. Y., \& Greenhow, C. M. (2014). Adolescents' visions of their future careers, educational plans, and life pathways: The role of bridging and bonding social capital experiences. Journal of Social and Personal Relationships, 31(4), 516-534. http://dx.doi.org/10.1177/0265407514523546.

Ferguson, K. M. (2006). Social capital and children's wellbeing: A critical synthesis of the international social capital literature. International Journal of Social Welfare, 15(1), 2-18. http://dx.doi.org/10.1111/j.1468-2397.2006.00575.x. 
Funch, D. P., \& Marshall, J. R. (1984). Self-reliance as a modifier of the effects of life stress and social support. Journal of Psychosomatic Research, 28(1), 9-15. http://dx.doi.org/ 10.1016/0022-3999(84)90035-7.

Goodwin-Smith, I., Hill, K., Due, C., Waterford, M., Corrales, T., Wood, L., ... Ho, C. (2017). 'I'm not a barcode or case file number': Understandings of perceived social support and belonging within disadvantaged adolescents and young adults. Journal of Family Studies, 1-17. http://dx.doi.org/10.1080/13229400.2016.1268191.

Granovetter, M. S. (1973). The strength of weak ties. American Journal of Sociology, 78(6), 1360-1380. http://dx.doi.org/10.1086/225469.

Groenendaal, J. H. A., \& van Yperen, T. A. (1994). Beschermende en bedreigende factoren. In J. Rispens, P. Goudena, \& J. Groenendaal (Eds.). Preventie van psychosociale problemen bij kinderen en jeugdigen. Bohn Stafleu van Loghum: Houten/Zaventem.

Gulliver, A., Griffiths, K. M., \& Christensen, H. (2010). Perceived barriers and facilitators to mental health help-seeking in young people: A systematic review. BMC Psychiatry, 10(1), 113. http://dx.doi.org/10.1186/1471-244X-10-113.

Hedge, J. M., Sianko, N., \& Mcdonell, J. R. (2017). Professional help-seeking for adolescent dating violence in the rural south: The role of social support and informal help-seeking. Violence Against Women, 23(12), 1442-1461. http://dx.doi.org/10. $1177 / 1077801216662342$

Jenson, J. M., \& Fraser, M. W. (2015). Social policy for children and families: A risk and resilience perspective. Thousand Oaks: Sage Publications.

Lauriks, S., de Wit, M. A., Buster, M. C., Fassaert, T. J., van Wifferen, R., \& Klazinga, N. S. (2014). The use of the dutch self-sufficiency matrix (SSM-D) to inform allocation decisions to public mental health care for homeless people. Community Mental Health Journal, 50(7), 870-878. http://dx.doi.org/10.1007/s10597-014-9707-x.

Lenkens, M., Rodenburg, G., Schenk, L., Nagelhout, G. E., van Lenthe, F. J., Engbersen, G., Sentse, M., Severiens, S., \& van de Mheen, D. (2018). "I need to do this on my own": Resilience and self-reliance in urban at-risk adolescents. (Manuscript submitted for publication).

Lin, N. (1999). Social networks and status attainment. Annual Review of Sociology, 25(1), 467-487. http://dx.doi.org/10.1146/annurev.soc.25.1.467.

Mackenzie, C. S., Gekoski, W. L., \& Knox, V. J. (2006). Age, gender, and the underutilization of mental health services: The influence of help-seeking attitudes. Aging \& Mental Health, 10(6), 574-582. http://dx.doi.org/10.1080/13607860600641200.

McCrae, R. R., \& Costa, P. T. (2003). Personality in adulthood: A five-factor theory perspective. Guilford Press.

Ortega, A. N., \& Alegría, M. (2002). Self-reliance, mental health need, and the use of mental healthcare among island puerto ricans. Mental Health Services Research, 4(3), 131-140. http://dx.doi.org/10.1023/A:1019707012403.

Portes, A. (1998). Social capital: Its origins and applications in modern sociology. Annual Review of Sociology, 24, 1. http://dx.doi.org/10.1146/annurev.soc.24.1.1.

Putnam, R. (2000). Bowling alone: The collapse and revival of American community. New York: Simon \& Schuster.

Raposa, E. B., Erickson, L. D., Hagler, M., \& Rhodes, J. E. (2018). How economic disadvantage affects the availability and nature of mentoring relationships during the transition to adulthood. American Journal of Community Psychology, 61(1-2), 191-203. http://dx.doi.org/10.1002/ajcp.12228.

Raymond-Flesch, M., Auerswald, C., Mcglone, L., Comfort, M., \& Minnis, A. (2017). Building social capital to promote adolescent wellbeing: A qualitative study with teens in a latino agricultural community. BMC Public Health, 17(1), 177. http://dx. doi.org/10.1186/s12889-017-4110-5.

Resnick, M. D., Bearman, P. S., Blum, R. W., Bauman, K. E., Harris, K. M., Jones, J., ... Shew, M. (1997). Protecting adolescents from harm: Findings from the national longitudinal study on adolescent health. JAMA, 278(10), 823-832. http://dx.doi.org/ 10.1001/jama.1997.03550100049038.

Rezai, S., Severiens, S., \& Crul, M. (2017). All hands on deck: Mechanisms of social support of the educationally mobile second generation in the Netherlands. Manuscript submitted for publication.

Rickwood, D., Deane, F. P., Wilson, C. J., \& Ciarrochi, J. (2005). Young people's helpseeking for mental health problems. Australian E-Journal for the Advancement of Mental Health, 4(3), 218-251. http://dx.doi.org/10.5172/jamh.4.3.218.
Rotter, J. B. (1966). Generalized expectancies for internal versus external control of reinforcement. Psychological Monographs: General and Applied, 80(1), 1. http://dx.doi. org/10.1037/h0092976.

Rutter, M. (1987). Psychosocial resilience and protective mechanisms. American Journal of Orthopsychiatry, 57(3), 316. http://dx.doi.org/10.1111/j.1939-0025.1987. tb03541.x.

Sadler, G. R., Lee, H., Lim, R. S., \& Fullerton, J. (2010). Recruitment of hard-to-reach population subgroups via adaptations of the snowball sampling strategy. Nursing \& Health Sciences, 12(3), 369-374. http://dx.doi.org/10.1111/j.1442-2018.2010. 00541.x.

Samuels, G. M., \& Pryce, J. M. (2008). "What doesn't kill you makes you stronger": Survivalist self-reliance as resilience and risk among young adults aging out of foster care. Children and Youth Services Review, 30(10), 1198-1210. http://dx.doi.org/10. 1016/j.childyouth.2008.03.005.

Scheidel, C. (2016). Elke jongere telt, programma Rotterdamse risicojongeren 2016-2020. Gemeente Rotterdam. Retrieved from: https://www.rotterdam.nl/wonenleven/elkejongere-telt/Programmaplan_ElkeJongereTelt_juni2017.pdf.

Schonert-Reichl, K. A., \& Muller, J. R. (1996). Correlates of help-seeking in adolescence. Journal of Youth and Adolescence, 25(6), 705-731. http://dx.doi.org/10.1007/ BF01537450.

Schwartz, S. E., Kanchewa, S. S., Rhodes, J. E., Cutler, E., \& Cunningham, J. L. (2016). "I didn't know you could just ask:" Empowering underrepresented college-bound students to recruit academic and career mentors. Children and Youth Services Review, 64, 51-59. http://dx.doi.org/10.1016/j.childyouth.2016.03.001.

Schwartz, S. E., Kanchewa, S. S., Rhodes, J. E., Gowdy, G., Stark, A. M., Horn, J. P., ... Spencer, R. (2018). "I'm having a little struggle with this, can you help me out?": Examining impacts and processes of a social capital intervention for first-generation college students. American Journal of Community Psychology, 61(1-2), 166-178. http://dx.doi.org/10.1002/ajcp.12206.

Scott, L. D., Mcmillen, J. C., \& Snowden, L. R. (2015). Informal and formal help seeking among older black male foster care youth and alumni. Journal of Child and Family Studies, 24(2), 264-277. http://dx.doi.org/10.1007/s10826-013-9832-0.

Smith, S. S. (2005). "Don't put my name on it": Social capital activation and job-finding assistance among the black urban poor. American Journal of Sociology, 111(1), 1-57. http://dx.doi.org/10.1086/428814.

Stanton-Salazar, R. D., \& Spina, S. U. (2000). The network orientations of highly resilient urban minority youth: A network-analytic account of minority socialization and its educational implications. The Urban Review, 32(3), 227-261. http://dx.doi.org/10. 1023/A:1005122211864.

Stanton-Salazar, R. D., \& Spina, S. U. (2005). Adolescent peer networks as a context for social and emotional support. Youth Society, 36(4), 379-417. http://dx.doi.org/10. 1177/0044118X04267814.

Szreter, S., \& Woolcock, M. (2004). Health by association? Social capital, social theory, and the political economy of public health. International Journal of Epidemiology, 33(4), 650-667. http://dx.doi.org/10.1093/ije/dyh013.

The Netherlands Institute for Social Research (SCP) (2014). Power to the people? A broad exploration of trends in civic participation. Den Haag: SCP7-14. Retrieved from https:/ www.scp.nl/english/Publications/Summaries by year/Summaries 2014/Power to the_people.

Tolsdorf, C. C. (1976). Social networks, support, and coping: An exploratory study. Family Process, 15(4), 407-417. http://dx.doi.org/10.1111/j.1545-5300.1976.00407.x.

Ungar, M. (2015). Practitioner review: Diagnosing childhood resilience-a systemic approach to the diagnosis of adaptation in adverse social and physical ecologies. Journal of Child Psychology and Psychiatry, 56(1), 4-17. http://dx.doi.org/10.1111/jcpp. 12306.

Vaux, A., Burda, P., \& Stewart, D. (1986). Orientation toward utilization of support resources. Journal of Community Psychology, 14(2), 159-170. http://dx.doi.org/10 1002/1520-6629(198604)14:2<159::AID-JCOP2290140207>3.0.CO;2-H.

Yosso, T. J. (2005). Whose culture has capital? A critical race theory discussion of community cultural wealth. Race Ethnicity and Education, 8(1), 69-91. http://dx.doi. org /10.1080/1361332052000341006. 